\title{
Critical Reflection in the Professional Development of Teachers: Challenges and Possibilities
}

MARJETA ŠARIĆ ${ }^{\star 1}$ AND BARBARA ŠTEH ${ }^{2}$

$\approx$ Critical reflection in teachers' professional development has received much attention in the scholarly literature, and there is an overwhelming consensus about its great significance to the quality of teachers' work. Nevertheless, despite the well-established role of reflection, a large gap between the professed goals and the actual reflective practice of teachers remains. The article starts with a short overview of the different definitions of critical reflection in the context of teachers' professional development and then underlines some empirical research findings on the problems that teachers and teacher educators face when putting reflective practice into practice, especially at the deeper and more complex levels of reflection. It continues with a consideration of teachers' qualifications for in-depth reflection as well as the obstacles and challenges facing teachers and teacher educators. The obstacles occur at the level of individual teachers' personal traits and at the level of the context in which reflection is done. Employing an analysis of the obstacles, the authors develop some guidelines on how to support teachers in their attempts at making critical reflection part of their teaching practice. It is crucial for this encouragement not to overlook the principal purpose of teachers' critical reflection; to contribute to new insights, knowledge reframing, and the introduction of such changes in teaching that will support students' learning and the development of the community for the better learning, work, and life of all its individuals.

Keywords: critical reflection, encouragement of critical reflection, professional development of teachers, teacher learning

$1{ }^{\star}$ Corresponding Author. University of Ljubljana, Faculty of Arts, Department of Educational Sciences, Slovenia; Marjeta.Saric@ff.uni-lj.si.

2 University of Ljubljana, Faculty of Arts, Department of Educational Sciences, Slovenia. 


\section{Kritična refleksija $\mathrm{v}$ profesionalnem razvoju učiteljev: izzivi in možnosti}

MARJETA ŠARIĆ IN BARbARA ŠTeH

$\propto$ Kritična refleksija v profesionalnem razvoju učiteljev je bila v znanstveni literaturi deležna že veliko pozornosti in uveljavljeno je strinjanje glede njenega velikega pomena za kakovostno delo učiteljev. Kljub utrjeni vlogi refleksije pa še vedno lahko zaznamo velik razkorak med deklariranimi cilji in dejansko refleksivno prakso učiteljev. V prispevku najprej predstaviva kratek pregled različnih opredelitev kritične refleksije $\mathrm{v}$ kontekstu profesionalnega razvoja učiteljev in poudariva nekaj izsledkov empiričnih raziskav o težavah, ki jih imajo učitelji in izobraževalci učiteljev pri udejanjanju refleksivne prakse, zlasti na globljih in kompleksnejših ravneh refleksije. V nadaljevanju obravnavava vprašanje usposobljenosti učiteljev za poglobljeno refleksijo ter ovire in izzive, s katerimi se učitelji in izobraževalci učiteljev srečujejo. Te ovire so na ravni osebnih značilnosti posameznih učiteljev in na ravni okoliščin, $\mathrm{v}$ katerih se kritična refleksija odvija. Na osnovi analize teh omejitev oblikujeva nekaj predlogov, s katerimi bi lahko podprli učitelje pri tem, da kritična refleksija postane sestavni del njihove prakse poučevanja. Pri tem spodbujanju je ključnega pomena, da ne pozabimo na temeljni namen kritične refleksije učiteljev, da prispeva $\mathrm{k}$ novim uvidom, prestrukturiranju znanja in k vpeljevanju takih sprememb v poučevanje, ki podpirajo učenje učencev in oblikovanje skupnosti za boljše učenje, delo in življenje vseh njenih članov.

Ključne besede: kritična refleksija, profesionalni razvoj učiteljev, spodbujanje kritične refleksije, učenje učiteljev 


\section{Introduction}

John Dewey's book How We Think (1910) is recognised as the origin of the notion of reflective thinking as a key element in learning. In his later work, Dewey emphasised the importance of reflective thinking in teachers, discriminating between routine and reflective action (Dewey, 1933 in Liu, 2015). When examining teachers' learning, we cannot overlook the ground-breaking work by Donald A. Schön Reflective Practitioner: How Professionals Think in Action (1983), in which the author emphasises the ability of teachers to reflect on their teaching as crucial to their professional development. It has had a significant impact on several teacher education programmes in the United States and throughout the world, which set themselves the goal of developing reflective teachers (Boud, 2010; Cvetek, 2003; Handal \& Lauvås, 1987; Korthagen, Kessels, Koster, Lagerwerf, \& Wubbels, 2001; Liu, 2015; Zeichner \& Liston, 1987). In Slovenia, Barica Marentič Požarnik $(1987,1993,2000)$ started writing about the teacher as a reflective practitioner as early as the 1980s and 1990s, when she was inquiring into how teachers should be educated and trained for well-thought-out, autonomous, and responsible action, which calls for - especially in conflicts - ethical considerations.

If teachers wish to foster active, meaning-directed, application-directed, self-regulated, and cooperative student learning, their roles become ever more demanding and complex (Vermunt, 2014). It no longer suffices to be able to explain the subject-matter well, to regulate their students' learning, and to motivate them to learn; rather, teachers must take on the new roles of diagnostician, challenger, model, activator, monitor, evaluator, and reflector of students' learning processes (Vermunt, 2014). Based on her literature overview, Liu (2015) emphasises that one of teachers' key competencies is being able to analyse and adapt their teaching to students in specific social, cultural and political contexts, which is especially challenging when teaching those students who are culturally, ethnically, and racially different from the majority of society, an issue that increasingly requires attention in current society. All these demanding and complex roles faced by the teacher require the ability to reflect critically.

Considering the numerous contributions to the topic of teachers' reflection, it is fair to say that it has established itself as a relevant issue in teachers' professional development and that authors seem to be unanimous in perceiving it as vital to the process of teachers' education and further professional development (Boud \& Walker, 1998; Cvetek, 2003, 2015; Handal \& Lauvås, 1987; Hatton \& Smith, 1995; Korthagen et al., 2001; Korthagen \& Vasalos, 2005; Loughran, 2002; Polak, 2010; Marentič Požarnik \& Lavrič, 2015; Rodgers, 2002; Rupnik Vec, 2006a; Valenčič Zuljan, 2008; Valenčič Zuljan \& Bizjak, 2007). 
It is, however, questionable whether teachers are adequately trained to follow up on this during their process of education or are provided with adequate conditions in their everyday pedagogical practice (school management's support, enough supervisors, time, etc.) and given support when reflecting on their teaching practice. Expecting that teachers will take time at their own initiative to integrate the process of reflection in their work deliberately is unrealistic. Undoubtedly, there are differences among teachers regarding both their readiness to engage in such reflection, as well as the quality and effectiveness of using reflection in professional learning (Moon, 2004; Van Eekelen, Vermunt, \& Boshuizen, 2006). When thinking about the factors of effectively introducing reflection to the professional learning of teachers, the following questions arise: how do teachers and teacher educators understand the process of reflection; why do they embark on the process; how and at what level is reflection done?

In this article, we would like to demonstrate that (although there is unanimity that reflection is crucial to teachers' professional development) researchers and teacher educators, as well as teachers themselves, understand reflection differently. Therefore, we will start by providing a short overview of different definitions of critical reflection and reflective practice and then proceed to several empirical research findings on the problems that educators and teachers have with reflective practice. The aim of this article is to examine current advances in understanding teachers' critical reflection, with a special emphasis on the gap between the high level of theoretical conception and the low level of reflection in teachers' practice. The specific purpose of the review of the empirical research literature is to show that the elaboration of critical reflection at the conceptual level has yet to be followed by the implementation in teachers' everyday practice. We will highlight the obstacles and challenges to the introduction and encouragement of teachers' (critical) reflection and, subsequently, establish some guidelines on the realisation of reflective practice.

\section{Theoretical Frameworks}

The definition of critical reflection in the literature on teachers' professional development is based on the work of John Dewey (e.g. Liu, 2015; Moon, 2004; Rodgers, 2002; Van Manen, 1995). Reflective thought, according to Dewey (1933 in Liu, 2015, p. 138), denotes 'active, persistent, and careful consideration of any belief or supposed form of knowledge in the light of the grounds that support it, and further conclusions to which it tends.' At its core lies the idea of systematically and rigorously examining an idea, an experience, a problem, with an attitude of open-mindedness, whole-heartedness, curiosity, and responsibility (Dewey, 1933 
in Rodgers, 2002). Since then, authors have defined reflection in a variety of ways, a good example of a single composite definition from different sources is the one by Tripp and Rich (2012, p. 678) who consider reflection 'as a self-critical, investigative process wherein teachers consider the effect of their pedagogical decisions on their situated practice with the aim of improving those practices'.

However, understanding and developing this central idea about the essence of reflection among researchers and teacher educators is different. This can be seen in the variety of models that have been proposed on the basis of Dewey's assumptions. There are long-standing debates and differences in interpreting what the process of reflection should look like in the actuality of teachers' professional lives (e.g. Boud, 2010; Cvetek, 2003; Korthagen \& Vasalos, 2005; Liu, 2015; Loughran, 2002; Van Manen, 1995). Reflection is considered as a basis for professional learning because it enables the learning process in and from the everyday classroom experience of teachers. One of the earliest definitions of reflection in the learning process is that it is a tool for the transformation of experience into knowledge (Boud, Keogh, \& Walker, 1985). With the promotion of reflection in professional education and teacher learning the conceptualisation of reflective practice has later widened and differentiated. Reflective practice includes several dimensions: besides the cognitive/intellectual dimension - reflection as a rigorous way of thinking - there are also the affective dimension (what the emotional aspect of the experience that is being reflected upon is), the motivational dimension (needs, desires, and goals in that situation), the personal dimension (personality characteristics of a reflective teacher), and the bodily dimension (reflection as an embodied practice) (Boud, 2010; Korthagen \& Vasalos, 2009; Rodgers, 2002; Van Manen, 1995). With the intention of fostering teacher reflection as well as furthering research there have been many attempts to construct a model or a framework to determine the type of reflection as practiced by teachers or, more commonly, student teachers (e.g. Hatton \& Smith, 1995; Jay \& Johnson, 2002; Korthagen \& Vasalos, 2005; Larrivee, 2008; Zeichner \& Liston, 1987). Most of the models include a category of 'critical reflection', and it is usually considered one of the higher levels of reflective practice.

Here, it should be emphasised that the 'critical' in 'critical reflection' can be understood in two ways. First, in the reflection process, the skills of critical thinking and critical orientation in thinking are used (e.g. curiosity or doubt, intellectual perseverance, etc.). Second, the emphasis on being critical in the reflection process refers to dealing with the issues that are related to the broader social context, power relations in social groups, and values and fundamental social questions (Hatton \& Smith, 1995; Liu, 2015; Van Manen, 1995; Zeichner \& Liston, 1987). Brookfield (1995 in Cvetek, 2003), who is a proponent of critical pedagogy, explains that the 
core of critical reflection lies in uncovering how within the educational process dominant social and economic groups impose their values and beliefs to legitimise their power and authority. Teachers' key task, therefore, is to learn how to recognise the workings of the system and create space for different action.

Zeichner and Liston (1996 in Liu, 2015) point out that teachers' reflection should not be supported as an end in itself without connecting these efforts to making a better society. Accordingly, the authors emphasise that it is important to ask the wider question of whether the results of our teaching are good, for whom and in what ways. Thus, it is essential for both aspects to be intertwined in our understanding of reflection. We should develop the skills of critical thinking to be able to recognise the assumptions that lie in the foundations of our beliefs and actions, to confront different perspectives, develop new alternatives and predict the consequences of actions and simultaneously create contextual sensitivity and reflective scepticism (Brookfield, 1993 in Rupnik Vec, $2006 \mathrm{~b}$ ). At the same time, it should not be forgotten the central purpose of the critical reflection of our own practice - to look for new solutions and paths, to introduce the changes that contribute to the transformation of the community for a better learning, work and life of all individuals.

Critical reflection in the context of education is thus characterised by teachers examining different topics (about themselves as learners and teachers, learning and teaching, social and political implications of schooling), by studying what values lie in the background and making others aware about in what direction epistemological starting points lead them when selecting teaching methods (Loughran, 2002; Rupnik Vec, 2006a; Sockett, 2008). In this process, it is necessary for the examined experience or problem to be restructured and reframed (Korthagen, 2001a; Schön, 1983), from this aspect creating new mental structures in knowledge has a key role (Evans, 1992 in Cvetek, 2003). Furthermore, as already emphasised, the crucial part of critical reflection is establishing critical awareness, that is, recognising the political nature of the profession through which the power relations of a society are revealed and maintained (Hatton \& Smith, 1995).

Liu (2015) underlines that there are differences between teacher educators and teachers in understanding critical reflection. To contribute to greater conceptual clarity and upgrade existing definitions, which may occasionally highlight only specific aspects of critical reflection, the author proposes the following complex definition of critical reflection, which - in addition to the processes that take place during reflection and the studied content - includes the ultimate purpose, which is often lacking in practice:

Critical reflection is a process of constantly analysing, questioning, and critiquing established assumptions of oneself, schools, and the society 
about teaching and learning, and the social and political implications of schooling, and implementing changes to previous actions that have been supported by those established assumptions for the purpose of supporting student learning and a better schooling and more justice society for all children. (pp. 144-145)

It is a goal that is difficult to achieve; nevertheless, it is important, to use Bečaj's (2009) words, that it defines our direction and, in that light, we judge the manners of encouraging reflection and the very process of the reflection of student teachers, teachers, and teacher educators. The main question is whether, in the given circumstances, the process of critical reflection is encouraged in the best possible way, contributing to new insights, knowledge reframing and the introduction of the changes in teaching that will support students' learning.

\section{Reflective Practice: Between Analytical and Holistic Approaches}

Approaches to performing and encouraging teachers' professional reflection vary. Some approaches are more systematically and analytically oriented, while others are more holistic and intuitive. Systematic and analytical approaches to reflection are typified by objectivity, personal distance, and observation separated from judgement. The models intended to foster reflection are clearly structured, often into hierarchical levels or multilevel models (e.g. Hatton \& Smith, 1995; Jay \& Johnson, 2002; Larrivee, 2008; Zeichner \& Liston, 1987). The levels typically range from more superficial to deeper levels of reflection, for example, the typology by Jay and Johnson (2002), which includes descriptive, comparative and critical dimensions with guiding questions to encourage reflection at different levels. Such models can greatly benefit studies of reflection and the introduction of students to reflective practice. Both students and many teachers can hardly imagine what good reflective practice means. Describing individual levels of reflection allows teacher educators to illustrate expected activities during the reflective process. Multilevel models are also practical when providing feedback on reflection depth, since educators can take the characteristics of individual reflection levels as assessment criteria. An instance is the analytical step separating interpretation from a detailed description of a working/learning situation. The description is normally followed by the analysis of hypotheses and alternative possibilities, a view on the issue from different perspectives, which is all accompanied by the awareness of the sociopolitical context. 
In contrast, there are holistic intuitive approaches that are philosophically and epistemologically founded in phenomenology, existentialism (Van Manen, 1977, 1995) and that reveal the influence of gestalt psychology (emphasising the significance of holistic images, including (in addition to conscious subject-matter) unconscious elements, and co-depending on needs, desires, values) (Korthagen, 2001b) as well as Eastern Buddhist thought (Tremmel, 1993) and the notion of presence (Meijer, Korthagen, \& Vasalos, 2009; Rodgers \& Raider-Roth, 2006). The goal of holistic approaches is raising awareness of implicit knowledge, reframing of existing schemes, confronting paradoxes, which enables more flexibility in unpredictable situations. These approaches typically include non-linguistic ways of reflection (e.g. the use of photos, metaphors, drawings); also, strong personal investment (fears, resistance) make the role of psychological security crucial (Korthagen et al., 2001). Holistic approaches are more challenging when applied to studying and encouraging reflection, because the non-linguistic and holistic features of a learning experience are not easy to formulate or express. Moreover, they do not lend themselves to exact and unequivocal assessment procedures, since there is no easy way to determine the 'progress' from one level to another. Besides, the pressures of assessment (of student teachers) or a demand for quick solutions (for teachers in practice) do not support exposing and confronting oneself with one's own perplexities and paradoxes that the holistic reflective processes entail.

Van Manen (1995) writes on teachers' practical knowledge and pedagogical tact, which he defines as 'an active intentional consciousness of thoughtful human interaction' (p. 43). According to Van Manen (1995), tactful action is instantaneous, and pedagogical tact likewise cannot be reduced to stages in a sequential process or a set of skills and techniques. Views of reflection as fostering doubt and criticism of one's own actions may turn out to be rather one-sided if they are understood as constant questioning. Acting in accordance with pedagogical tact, however, requires confidence in one's actions in unpredictable and ever-changing situations. Like Van Manen (1995), Korthagen (2001b) and Tremmel (1993) also stress the one-sidedness of the glorification of the rational aspects of reflection. All the authors mentioned argue against the strict divide or exclusive primacy of one or the other approaches to reflective practice; they incisively argue for the importance of both so that one-sidedness could be avoided. Korthagen (2001b, p. 237) states: 'I believe that especially the integration of both types of reflection (the mirroring of non-rational processes and rational analysis) would be beneficial, because they are directly related to the two different ways in which the teacher's consciousness operates.' The authors advocate a better balance between the two approaches and consistent support for teachers in their professional work. 


\section{Critical Reflection in (Student) Teaching Practice: Where Has the 'Critical' Gone?}

The role of reflection in teachers' professional development is often written and spoken about. However, it remains an open question of whether during teacher education and in-service teacher training teachers are prepared for the critical reflection on their own teaching practice, which they seem to perceive as an indispensable part of their professional development. Zeichner (1992 in Liu, 2015, p. 137), finds 'that there is much research on preparing reflective teachers, but most of it focuses on prospective teachers' perceptions and selfreported results, with little consideration of their reflection in terms of process or the presence (or lack) of a critical nature'. Let us now consider some research findings that show what levels reflection can reach and what its quality may be.

Mansvelder-Longayroux, Verloop, Beijaard, and Vermunt (2007) studied student teachers' learning activities and self-regulation of learning through the analysis of their portfolios by looking for the presence of six types of learning activities: recollection, evaluation, analysis, critical processing, diagnosis, and reflection. The results showed that recollecting and evaluating activities dominated overwhelmingly (93\% of the 1,778 learning activities identified in 39 portfolios). 'Recollecting', in this case, meant that an event was described that had already occurred. The participants described the events that had occurred, for instance, during school classes and evaluated them (e.g. that they went well, wrong, badly, etc.), even before they critically reflected on them from different perspectives (what had led to certain actions, how certain actions influenced the achievement of learning goals, how the participants experienced them, etc.), which are the key characteristics of critical reflection (Korthagen \& Vasalos, 2005). Mansvelder-Longayroux et al. (2007) determined that the learning activities that referred to a deep approach and self-regulation in learning (analysis, diagnosis, critical processing, or reflection of or on those events) only rarely $(7 \%)$ emerged in the student teachers' portfolios.

A similarly low level of reflection was established by Polak (1995), having examined student class-teachers' practical-work diaries. In their thoughts on practical-work experiences, the students remained at the level of reporting. Cvetek (2003) similarly assessed future English-teachers' qualifications for critical reflection on their teaching on the basis of their written reports on practical pedagogical work. The author asked the students to describe and evaluate some of the so-called 'critical events' from their practical work. He classified the students' $(n=49)$ responses according to the hierarchical model of content levels of writing proposed by O'Hanlon: (1) the level of reporting, (2) the level 
of interpretation, (3) the level of the consequences or reflection, (4) the level of the integration of the personal and the professional. The author determined that $24 \%$ of the reports were at the level of reporting, $57 \%$ of them reached the level of interpretation in certain parts, only $18 \%$ of the reports reached the level of reflection, and none were at the integrational level.

Valenčič Zuljan and Bizjak (2007), in contrast, did not focus on the quality of reflection by future teachers; rather, they studied the qualifications of teacher mentors to reflect on their own practice and to encourage reflection in their trainees. Using qualitative analysis of diary entries categorised according to the taxonomy of reflective thinking by Handal and Lauvås (1987 in Valenčič Zuljan \& Bizjak, 2007) as being at the level of immediate practice, the level of arguments or the level of ethics, they established that mentoring consists mainly of activities at the first level of reflection. They could not classify any of the entries as belonging to the third level, which includes the ethical dimension of reflection. Such teacher mentors are therefore not good role models to introduce their younger colleagues to reflective practice: they tend to give advice without encouraging the trainees to highlight their teaching from different aspects.

Bakkenes, Vermunt, and Wubbels (2010) scrutinised the learning activities and learning outcomes of experienced teachers, which they divided into six categories. In this study, the teachers most frequently reported (1) reflecting on one's own teaching practice and/or students' learning or functioning (33\% of all the 735 reported learning activities), and (2) experimenting, when purposefully trying out something new in practice and some form of reflection on it (32\%). More rarely, they reported (3) getting ideas from others (15\%), (4) experiencing friction, noticing a discrepancy between what one expects or wants and what happens in class $(15 \%)$, (5) struggling not to revert to old ways (5\%), and (6) avoiding learning (1\%) (Bakkenes et al., 2010). Teachers do emphasise the process of reflection as crucial to their learning, but what its quality is and how they may be supported in their critical reflection remains uncertain.

Marentič Požarnik (2013) analysed a number of the reports that were produced for the clear and well-managed project of reading literacy, ${ }^{3}$ which included numerous schools, and came across certain weaknesses related to monitoring and explaining the process. This indicates the part connected to the reflection on the measures and activities, and again it turns out that only rarely did more careful or critical considerations of whether the activities followed the plans, what influenced their (in)effectiveness, students' responses, why some measures were more and others were less effective, whether there

3 The project of reading literacy is the responsibility of a team at the National Education Institute Slovenia headed by Dr Fani Nolimal (Marentič Požarnik, 2013). 
were any doubts, dilemmas, etc. occur. The descriptions generally clearly and convincingly documented actions and events, but in-depth critical reflection was lacking. Thus, the way teacher educators could encourage student teachers' and teachers' reflective practice into a more sophisticated, critical practice that will, in turn, transform their learning, which will lead to changes in their understanding, attitudes and actions remains an open issue.

\section{Challenges and Guidelines Regarding Fostering the Critical Reflection of Teachers}

In supporting teachers to engage in the process of critical reflection, a number of challenges are encountered. The ever more popular and apparently self-evident teachers' reflective practice also reveals a simplified understanding of critical reflection (Liu, 2015). Moon (2004, p. 88) lists a selection of one-sided views of what reflection is, which may limit further understanding and transition to in-depth reflection: 'emotion is central to reflective processes', 'reflection is about "my own" processes (i.e., always in the first person), 'some people cannot reflect'. Later, it will be seen that emotions can play highly diverse roles in the process of reflection, that it is positive if someone can help us examine ourselves in the mirror, looking at what our attitudes towards specific phenomena are, etc., and that reflection is not just a function of the individual's level of experience, but that our readiness for the process of reflection differs from situation to situation, that it is not always a conscious activity and may not be done willingly when required.

Boud and Walker (1998) have identified 'a number of problems that have arisen from the application of ideas about reflection in higher education courses' (p. 192), such as reflection as recipe-following, reflection without learning, the belief that reflection can be easily contained (when students are put in considerable distress and tensions when exploring dilemmatic or ethically dubious situations), incongruence with a formal learning context (assessment issues), or intellectualising reflection. Other problems are inappropriate disclosure, uncritical acceptance of learners' experiences, going beyond the expertise of the teacher, and excessive use of teacher power. The authors suggest that the influence of context is an important factor in facilitating reflective practice that is always embedded in a particular social setting with a set of cultural practices. In addition to context, Boud (2010) later adds the importance of personal characteristics, dispositions, motives, feelings, ideas, and conceptions about oneself and the world, which shape the way reflective practice is enacted.

Let us take a closer look, first, at some personal traits that have an impact on how critical reflection is done. Despite general and widely accepted 
expectations for teachers to be engaged in life-long professional learning, there are considerable differences among teachers in their motivation to learn; not all teachers want to inquire into the potential significance or meaning of their everyday work experience (Rodgers, 2002; Van Eekelen, Vermunt \& Boshuizen, 2006). In a small-scale qualitative study with 15 experienced teachers, Van Eekelen et al. (2006) distinguished three groups of teachers: those who did not see the need to learn, those who wondered how to learn but wanted a straightforward solution or the 'right' answer and, finally, the teachers who were eager to learn. Selkrig and Keamy (2015) studied collegial conversations among educators, and they noticed how difficult it is to go beyond surface-level discussions to genuine collaboration in order to deepen professional learning. Curiosity, willingness to wonder, open-mindedness, and desire for growth have all been mentioned as motives for engaging in meaningful learning since Dewey (in Rodgers, 2002; also, Korthagen et al., 2001; Selkrig \& Keamy, 2015).

Mezirow (1990 in Liu, 2015, p. 145) maintains that critical reflection includes questioning one's self-conception and such challenges are always fraught with threat and strong emotions. It is not an easy task to cope with the emotions that accompany repetitive thought, because these repetitive self-thoughts can be more or less (non)constructive (Watkins, 2008). This distinction is conceptualised in psychological literature as the difference between reflection and rumination (Takano \& Tanno, 2009). Ruminative thought is oriented more towards perceived threats and injustices to one's self and is related to clinical disorders, depressive symptoms, intrusive thoughts and worry, while the reflective thought is more open, playful and exploratory, and as such leads to accurate self-perception (Trapnell \& Campbell, 1999). Considering these differences in the light of fostering reflective thought processes, it is, therefore, important to be aware that not all self-focused thought is constructive; moreover, some thinking patterns can even lead to negative consequences for the people inclined to ruminative thinking. Knowledge of the workings of one's own mind is, therefore, an important part of critical reflection, and Tremmel (1993) emphasises the habit of mind (especially paying attention and mindfulness) as an important feature of reflection. Similarly, Rodgers (2002) explains Dewey's notion of directness in reflective thought as being free from self-absorption.

As mentioned above, another challenge in the practice of critical reflection is its emotional dimension. Emotions can be involved in the process of critical reflection in several ways (Moon, 2004). First, they are often the reason for engaging in reflection - a puzzling event that has left a teacher with unresolved feelings of anger, disappointment, or wonder that mobilises her/him to start exploring the event and looking for ways to understand it (Rodgers, 2002; 
Šarić, 2015). As such, the emotions that started the process of inquiry can be the content of reflection among the other features of the perplexing learning experience (Korthagen \& Vasalos, 2005; Moon, 2004; Šarić, 2015). Second, the process of reflection can become a source of an emotional experience, when we face the less well-known parts of ourselves or when the foundations of our identity are shaken up due to the reframing of our understanding. Finally, the result of reflection is such that it can influence the teacher's subsequent emotional experience and regulation of emotions (Moon, 2004; Šarić, 2015).

However, the individual's characteristics do not have an impact on teachers' reflective practice in isolation, but always within a certain context (Boud \& Walker, 1998). Dominant cultural assumptions and the practices of an educational organisation, particular disciplinary and professional contexts, the micro-contexts of sub-groups - all these define the frame within which the process of reflection takes place. Vermunt (2014) asserts that the most direct and important contextual factor that influences teachers' learning is the type of the learning environment. Studies reviewed by Vermunt (2014, p. 90) reveal that 'organised learning environments (peer coaching, collaboration in teams) turned out to elicit qualitatively better learning activities and learning outcomes than informal workplace learning. In a study of collaborative inquiry more specific to the area of critical reflection, Pareja Roblin and Margalef (2013) confirmed that those teachers who acknowledged and embraced the dilemmas from their common work, were taking 'critical perspective on their educational beliefs and practice, thereby strengthening their critical reflection' (p. 30).

Another contextual factor is the way in which the reflective process is encouraged in the context of an educational programme. We should not overlook that training for reflective teaching starts at university and that it is only possible in the education that accepts theoretical and practical aspects as equal and as interactively interlinked. It allows student teachers to use their experience and critical thinking to test existing theories and to formulate new theories and knowledge, which can become the foundation for further action in practice (Cvetek, 2003; Handal \& Lauvås, 1987) or in the so-called realistic approach to teacher education (Korthagen, 2005, 2017; Korthagen et al., 2001). It is necessary for the development of critical reflection to become part of the curriculum, to be an important goal in teacher education. There is a certain danger, of course, that it may become just another obligation to fulfil (a reflective diary or lesson analysis to write) or another course to pass. It should not be forgotten that encouraging learning and reflection can oppose the controlling function of assessment (Šteh \& Šarić, 2016). For instance, students are to be encouraged to reflect on their own learning in order to shed light on their strong and weak 
areas, but they feel uneasy about disclosing their thoughts and emotions, having summative assessment in mind, which will require them to prove that they have mastered a specific field. They are afraid to show their weaknesses during the process of reflection, since they wish to impress the teacher during the process of learning. Hobbs (2007) highlights how the pressure to perform well undermines genuine and authentic reflection. She proposes careful consideration in introducing reflective activities in the programmes and courses, taking into account the principles of gradualness, active involvement of student teachers, and postponing or refraining from the assessment of reflective practice.

It is crucial to be aware that critical reflection cannot be reduced to a mere set of prescribed steps and techniques, nor can it be conducted at a merely rational level (Korthagen, 2001b; Van Manen, 1995). We should consider that student teachers' or teachers' learning processes are multi-dimensional (in each person the cognitive, affective and motivational sources of behaviour are intertwined, and embedded in a social context), multi-level in nature and often unconscious (Korthagen, 2017).

The challenge for teacher educators lies in how to make critical reflection part of their own teaching practice and how to become models of reflective practice for student teachers. Korthagen (2017) emphasises that, when fostering professional development, it is necessary to link the professional and personal aspects of learning and that we usually neglect the deeper levels: professional identity and mission. The task of educational organisations, especially those that educate teachers, is developing a culture that will permit and welcome questioning one's actions, reasons, views and looking for solutions for always-changing dilemmas and challenges that everyday learning (life) situations bring. Student teachers' as well as (later) teachers' autonomous action should be enabled and supported. This, however, is not possible in the environments that require constantly proving oneself and that determine and reflect the quality of teachers' learning and work in nothing but a series of measurable indicators (Tickle, 2005).

\section{Conclusion}

We have analysed in some detail the various connotations and characteristics of critical reflection from Dewey onward, created a number of models to develop critical reflection, and defined the conditions for its quality enactment. Nevertheless, a large gap between the professed goals and the actual reflective practice of teachers remains. There are no quick fixes with regard to encouraging teachers' professional development or to developing critical reflection. Korthagen (2017) summarises the conclusions of different authors and 
points out that an inconvenient truth may be that effective professional development is primarily value-based, much more open-ended and, to a certain degree, more unpredictable than traditional approaches, as it often requires deep cultural change.

We have derived several guidelines for introducing and fostering (student) teachers' reflection based on the challenges discussed previously. Firstly, in introducing reflection, we need to consider the influence of the contextual factors, such as organisational culture, educational programme, assessment issues, etc. Secondly, as teacher educators we encourage reflective practice when we consider individual characteristics of (student) teachers (motivation for reflection, critical thinking skills, etc.). By implementing reflective practice, we should not undermine the motives that are beneficial for critical reflection: curiosity, willingness to wonder, open-mindedness, and desire for growth. Thirdly, it is important to differentiate between constructive and nonconstructive self-focused thought. Lastly, being attentive to the emotional dimension of reflective practice supports students in their vulnerability and simultaneously encourages them to follow the abovementioned motives to explore the complexities of their own teaching practice.

Critical reflection is only possible in the environments in which doubt about certain views and actions is allowed and where individuals are willing to doubt and broaden the limits of their comfort zones. However, this requires mutual support and a degree of confidence - if nothing else, the confidence that individuals can learn better and make headway. At the same time, the central purpose of critical reflection must not be forgotten - to look for new solutions and paths, to introduce the changes which contribute to the transformation of the community for the better learning, work and life of all its individuals.

\section{Acknowledgements}

The authors acknowledge the financial support from the Slovenian Research Agency (research core funding No. P5-0174, Pedagogical and andrological studies - Learning and education for a good quality life in community). 


\section{References}

Bakkenes, I., Vermunt, J. D., \& Wubbels, T. (2010). Teacher learning in the context of educational innovation: Learning activities and learning outcomes of experienced teachers. Learning and Instruction, 20(6), 553-548.

Bečaj, J. (2009). Cilji so vedno v oblakih, pot pa je mogoča le v resničnosti [Goals are alwys in the clouds, the way is possible only in actual reality]. Vzgoja in izobraževanje, 4o(jubilee issue), 27-40. Boud, D. (2010). Relocating reflection in the context of practice. In H. Bradbury, N. Frost S.

Kilminster, \& M. Zukas (Eds.), Beyond reflective practice: new approaches to professional lifelong learning (pp. 25-36). Abingdon: Routledge.

Boud, D., Keogh, R., \& Walker, D. (1985). Reflection: Turning Experience into Learning. London: Kogan Page.

Boud, D., \& Walker, D. (1998). Promoting reflection in professional courses: The challenge of context. Studies in Higher Education, 23(2), 191-206.

Cvetek, S. (2003). Refleksija in njen pomen za profesionalno usposobljenost učiteljev. [Reflection and its significance in terms of the professional qualification of teachers]. Sodobna pedagogika, 54(1), 104-121.

Cvetek, S. (2015). Učenje in poučevanje v visokošolskem izobraževanju, Teorija in praksa [Learning and teaching in higher education: Theory and practice]. Ljubljana: Buča.

Dewey, J. (1910). How we think. Boston: D. C. Heath \& Co. Publishers.

Handal, G., \& Lauvås, P. (1987). Promoting reflective teaching: Supervision in practice. Milton Keynes: SRHE in Open University Press.

Hatton, N., \& Smith, D. (1995). Reflection in teacher education: Towards definition and implementation. Teaching and Teacher Education, 11(1), 33-49.

Hobbs, V. (2007). Faking it or hating it: Can reflective practice be forced? Reflective Practice, 8(3), 405-417.

Jay, J. K., \& Johnson, K. L. (2002). Capturing complexity: a typology of reflective practice for teacher education. Teaching and Teacher Education, 18(1), 73-85.

Korthagen, F. A. J. (2001a). A reflection on reflection. In F. A. J. Korthagen, J. Kessels, B. Koster, B. Lagerwerf, \& T. Wubbels (Eds.), Linking practice and theory: The pedagogy of realistic teacher education (pp. 51-68). Mahwah, NJ: Lawrence Erlbaum Associates.

Korthagen, F. A. J. (2001b). A broader view of reflection. In F. A. J. Korthagen, J. Kessels, B. Koster, B. Lagerwerf, \& T. Wubbels (Eds.), Linking practice and theory: The pedagogy of realistic teacher education (pp. 231-238). Mahwah, NJ: Lawrence Erlbaum Associates.

Korthagen, F. A. J. (2005). Practice, Theory, and Person in Life-Long Professional Learning. In D. Beijaard, P. C. Meijer, G. Morine-Dershimer, \& H. Tillema (Eds.), Teacher Professional Development in Changing Conditions (pp. 79-94). Dordrecht: Springer.

Korthagen, F. (2017). Inconvenient truths about teacher learning: towards professional development 3.0. Teachers and Teaching: theory and practice, 23(4), 387-405. 
Korthagen, F. A., Kessels, J., Koster, B., Lagerwerf, B., \& Wubbels, T. (2001). Linking practice and theory: The pedagogy of realistic teacher education. Mahwah, NJ: Lawrence Erlbaum Associates. Korthagen, F. A. J., \& Vasalos, A. (2005). Levels in reflection: core reflection as a means to enhance professional growth. Teachers and Teaching: theory and practice, 11(1), 47-71.

Korthagen, F. A. J., \& Vasalos, A. (2009, August). From reflection to presence and mindfulness: 30 years of developments concerning the concept of reflection in teacher education. Paper presented at the EARLI conference, Amsterdam.

Larrivee, B. (2008). Development of a tool to assess teachers' level of reflective practice. Reflective Practice, 9(3), 341-360.

Liu, K. (2015). Critical reflection as a framework for transformative learning in teacher education.

Educational Review, 67(2), 135-157.

Loughran, J. J. (2002). Effective reflective practice: In search of meaning in learning about teaching. Journal of Teacher Education, 53(1), 33-43.

Mansvelder-Longayroux, D. D., Beijaard, D., \& Verloop, N. (2007). The portfolio as a tool for stimulating reflection by student teachers. Teaching and Teacher Education, 23(1), 47-62.

Marentič Požarnik, B. (1987). Nova pota v izobraževanju učiteljev [New paths in teacher education].

Ljubljana: Državna založba Slovenija.

Marentič Požarnik, B. (1993). Kako se učijo učitelji? [How teachers learn?]. Vzgoja in izobraževanje, $24(1), 13-15$.

Marentič Požarnik, B. (2000). Profesionalizacija izobraževanja učiteljev - nujna predpostavka uspešne prenove [Professionalization of teacher education - necessary precondition of successful school reform]. Vzgoja in izobraževanje, 31(4), 4-11.

Marentič Požarnik, B. (2013). Uveljavljanje prvin akcijskega raziskovanja v projektu bralna pismenost [Establishing elements of action research in reading literacy project]. Vzgoja in izobraževanje, 44(2-3), 16-21.

Marentič Požarnik, B., \& Lavrič, A. (2015). Kako se učijo učitelji: (video) povratna informacija kot spodbuda za učiteljev profesionalni razvoj [How teachers learn: (Video)feedback as an encouragement for teachers' professional development]. Vzgoja in izobraževanje, 46(1), 7-15. Meijer, P. C., Korthagen, F. A. J., \& Vasalos, A. (2009). Supporting presence in teacher education: The connection between the personal and professional aspects of teaching. Teaching and Teacher Education, 25(2), 297-308.

Moon, J. A. (2004). A handbook of reflective and experiential learning: Theory and practice. London: Routledge Falmer.

Pareja Roblin, N., \& Margalef, L. (2013). Learning from dilemmas: teacher professional development through collaborative action and reflection. Teachers and Teaching, 19(1), 18-32.

Polak, A. (1995). Kaj nam razkrivajo dnevniki pedagoške prakse? [What are teachers' practicum journals revealing?] Vzgoja in izobraževanje, 26(2), 19-22.

Polak, A. (2010). Refleksija pedagoškega dela v vrtcu: razsežnosti in pomen za profesionalni razvoj [Reflection in preschool education: Dimensions and significance for professional development]. In T. 
Devjak, M. Batistič-Zorec, J. Vogrinc, D. Skubic, \& S. Berčnik (Eds.), Pedagoški koncept Reggio Emilia in Kurikulum za vrtce: podobnosti v različnosti (pp. 431-444). Ljubljana: Pedagoška fakulteta.

Rodgers, C. R. (2002). Defining reflection: Another look at John Dewey and reflective thinking. Teachers College Record, 104(4), 842-866.

Rodgers, C. R., \& Raider-Roth, M. B. (2006). Presence in teaching. Teachers and Teaching: Theory and practice, $12(3), 265-287$.

Rupnik Vec, T. (2006a). Kritična samorefleksija - temelj profesionalnega razvoja in rasti [Critical self-reflection - A foundation of professional development and growth]. Socialna pedagogika, 10(4), $429-465$.

Rupnik Vec, T. (2006b). Pojmovanja kritičnega mišljenja [Concpetions of critical thinking]. In T. Rupnik Vec, \& A. Kompare (Eds.), Kritično mišljenje v šoli (pp. 9-54). Ljubljana: Zavod Republike Slovenije za šolstvo.

Schön, D. A. (1983). Reflective practitioner: How professionals think in action. New York: Basic Books. Selkrig, M., \& Keamy (R.) K. (2015). Promoting a willingness to wonder: moving from congenial to collegial conversations that encourage deep and critical reflection for teacher educators. Teachers and Teaching, 21(4), 421-436.

Sockett, H. (2008). The moral and epistemic purposes of teacher education. In M. Cochran-Smith, S. Feiman-Nemser, D. J. McIntyre, \& K. E. Demers (Eds.), Handbook of Research on Teacher Education: Enduring questions in changing contexts (pp. 45-65). New York: Routledge.

Šarić, M. (2015). Refleksija kot orodje za prepoznavanje in predelovanje čustev učiteljev pri delu (neobjavljena doktorska disertacija) [Reflection as a tool for teachers' emotion recognition and regulation, unpublished doctoral dissertation]. Ljubljana: University of Ljubljana, Faculty of Arts. Šteh, B., \& Šarić, M. (2016). Ocenjevanje v visokem šolstvu: ovira ali spodbuda za kakovosten študij [Assessment in higher education: An obstacle or an encouragement for quality study]. In K. Aškerc (Ed.), Improving the quality of teaching and learning in higher education (pp. 64-69). Ljubljana: Center RS za mobilnost in evropske programme izobraževanja in usposabljanja.

Takano, K., \& Tanno, Y. (2009). Self-rumination, self-reflection, and depression: Self-rumination counteracts the adaptive effect of self-reflection. Behaviour Research and Therapy, 47(3), 260-264. Tickle, L. (2005). The crucible of the classroom: A learning environment for teachers or a site of crucifixion? In D. Beijaard, P. C. Meijer, G. Morine-Dersheimer, \& H. Tillema (Eds.), Teacher professional development in changing conditions (pp. 61-77). Dordrecht: Springer.

Trapnell, P. D., \& Campbell, J. D. (1999). Private self-consciousness and the five-factor model of personality: Distinguishing rumination from reflection. Journal of Personality and Social Psychology, 76(2), 284-304.

Tremmel, R. (1993). Zen and the art of reflective practice in teacher education. Harvard Educational Review, 63(4), 434-458.

Tripp, T., \& Rich, P. (2012). Using video to analyze one's own teaching. British Journal of Educational Technology, 43(4), 678-704.

Valenčič Zuljan, M. (2008). Učitelj na putu profesionalnog razvoja. Od početnika do eksperta [Teacher 
on the way of professional development: From beginner to expert]. Vršac: Visoka škola strukovnih studija za obrazovanje vaspitača »Mihailo Palov« Vršac.

Valenčič Zuljan, M., \& Bizjak, C. (2007). A Mentor Between Supporting and Challenging a Novice’s Reflection. In M. Valenčič Zuljan, \& J. Vogrinc (Eds.), Professional Induction of Teachers in Europe and Elsewhere (pp. 309-323). Ljubljana: Faculty of Education.

Van Eekelen, I. M., Vermunt, J. D., \& Boshuizen, H. P. A. (2006). Exploring teachers' will to learn. Teachers and Teaching Education, 22(4), 408-423.

Van Manen, M. (1977). Linking ways of knowing with ways of being practical. Curriculum Inquiry 6(3), 205-228.

Van Manen, M. (1995). On the epistemology of reflective practice. Teachers and Teaching: theory and practice, $1(1), 33-50$.

Vermunt, J. D. (2014). Teacher Learning and Professional Development. In S. Krolak-Schwerdt, S. Glock, \& M. Böhmer (Eds.), Teachers' Professional Development: Assesment, Training, and Learning (pp. 79-95). Rotterdam, Boston, Taipei: Sense Publishers.

Watkins, E. R. (2008). Constructive and unconstructive repetitive thought. Psychological Bulletin, 134(2), 163-206.

Zeichner K. M., \& Liston, D. P. (1987). Teaching student teachers to reflect. Harvard Educational Review, 57(1), 23-48.

\section{Biographical note}

MARJETA ŠARIć, PhD in psychology, works as Assistant at the Department of Educational Sciences, Faculty of Arts, University of Ljubljana. Her research interests include emotions in teaching, teachers' beliefs, and reflection in teachers' professional development. She is active in fostering the quality of learning and teaching in higher education by conducting workshops for academic staff.

BARBARA ŠTEH, PhD in psychology, is Associate Professor at the Department of Educational Sciences, Faculty of Arts, University of Ljubljana, Slovenia. She teaches several undergraduate and graduate courses: Educational Psychology, Selected Themes in Educational Psychology, Psychology of Learning in Adult Education, and Experiential Learning. In her own teaching, she implements active and experience-based teaching methods and mentors many students. She also runs many workshops and seminars for in-service teacher training for teachers at all levels and educational advisors. Her research interests include the quality of learning and teaching, the quality of higher education, implementation of active learning methods, the cooperation between school and community, and teachers' professional development. 